"Structured personal conflict as a main determinant of intragroup conflict: a study in Mexico"

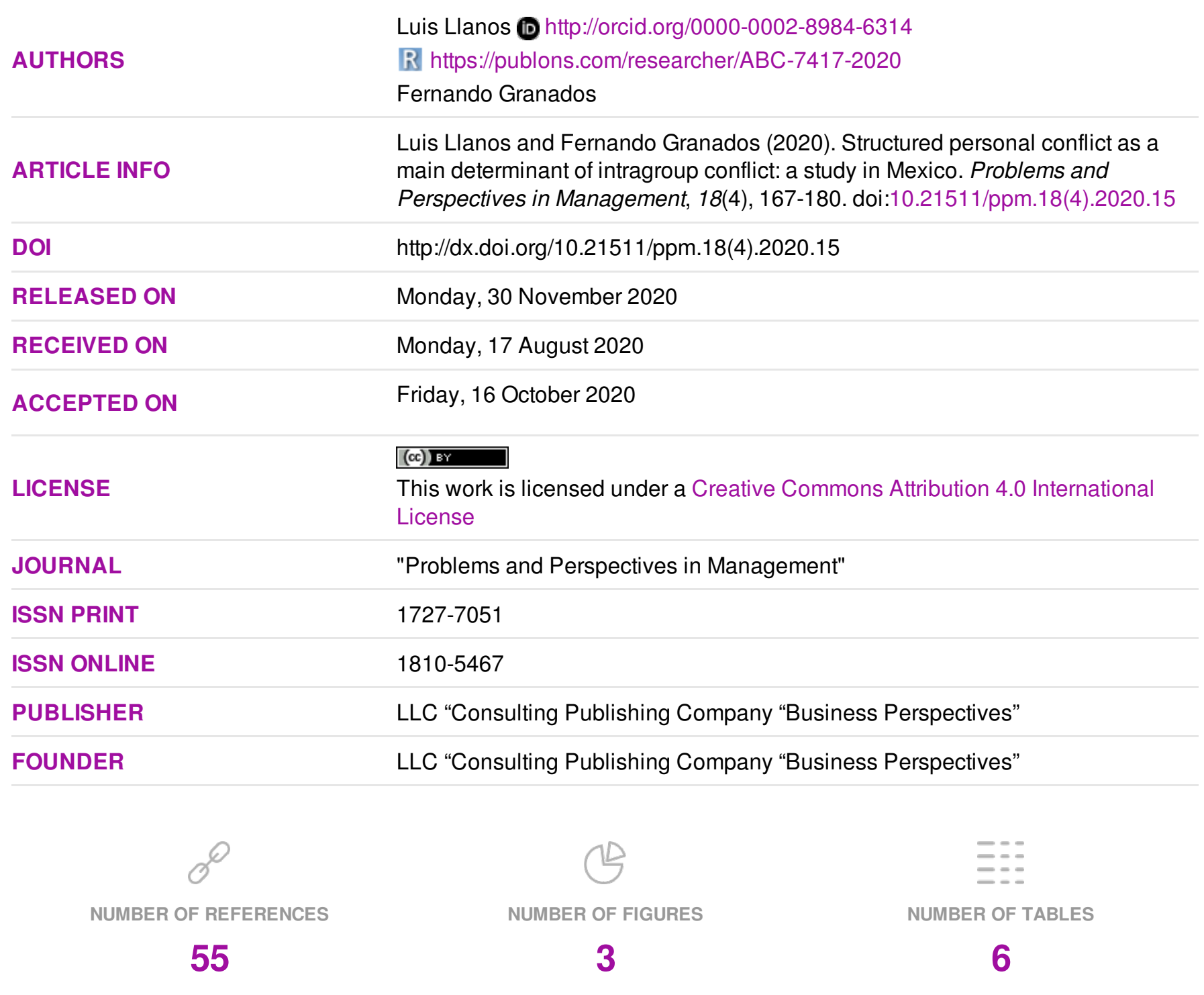

(C) The author(s) 2023. This publication is an open access article. 


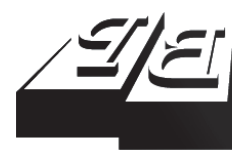

BUSINESS PERSPECTIVES

(O)

LLC "CPC "Business Perspectives"

Hryhorii Skovoroda lane, 10

Sumy, 40022, Ukraine

www.businessperspectives.org
Received on: $17^{\text {th }}$ of August, 2020 Accepted on: $16^{\text {th }}$ of October, 2020 Published on: $30^{\text {th }}$ of November, 2020

() Luis Llanos,

Fernando Granados, 2020

Luis Llanos, Ph.D., Research Professor, Department of Leadership and

Management, Business and Economic

Faculty, University Anahuac, Mexico. (Corresponding author)

Fernando Granados, Ph.D., Research Professor, Department of Business Strategy, Business and Management Faculty, University Anahuac, Mexico.

\section{STRUCTURED PERSONAL CONFLICT AS A MAIN DETERMINANT OF INTRAGROUP CONFLICT: A STUDY IN MEXICO}

\begin{abstract}
Managers can spot and target the common driving forces of conflicting employees to ensure their efficiency and productivity. The aim of this research is to provide evidence for the existence of a personal profile, named in this work Structured Personal Conflict, which is present in intragroup conflicts, traditionally studied based on the factoring of conflicts of processes, results and relationships. More than 400 questionnaires were distributed by mail among workers from different organizations and jobs in Mexico, the methodology used the information of 201 usable questionnaires. Various goodnessof-fit tests obtained were applied and rival models were compared using Confirmatory Factor Analysis (AFC). As a result, it was found that structured personal conflict can be estimated from the intragroup conflicts of processes, results and relationships, and that it has a greater explanatory power than either of them individually. The importance of structured personal conflict in the personnel selection and in the performance of teams should be emphasized.
\end{abstract}

Keywords

JEL Classification task conflict, process conflict, relationship conflict, endogenous factors, selection of personnel, Mexico

\section{INTRODUCTION}

According to some authors such as Greer et al. (2008), De Witt et al. (2012) and De Church et al. (2013), intragroup conflict is a process that begins when an individual or group perceives differences and opposition between himself and others about incompatibilities of interests, resources, beliefs, values or practices. Pondy (1992) and Jehn (1994, 1997) identified the categories for the intragroup conflict: processes, tasks and relationships; De Witt et al. (2013) proposed considering individual perceptions in future research, since this variable could affect the collective phenomenon.

Ayub et al. (2017) establish that the Big Five theory is one of the successful theories in predicting behavior at work. The authors identify that personality traits, during the conflict management process, determine performance.

This study contributes to the discussion about individual perceptions by demonstrating the existence of a conflict named Structured personal conflict, which can be distinguished from exogenous conflicts to the person. The study seeks to provide more evidence of how personal conflict stands out over any other type of conflict at work and requires consideration to define how to handle it and thus avoid group failure. 


\section{LITERATURE REVIEW}

Some studies indicate that members of a group distinguish their intragroup conflicts within three categories: i) with internal processes (De Witt et al., 2012; Vodosek, 2007), however, different opinions may even be presented among the members regarding the severity of each of them (Amason, 1996; Jehn \& Chatman, 2000; Jehn et al., 2010), ii) with the tasks to be performed (De Witt et al., 2012; Lê \& Jarzabkowski, 2015; Vodosek, 2007), and iii) with interpersonal relationships (Jehn \& Mannix, 2001; Jehn et al., 2008).

The literature is reviewed in the following order: the main theories of intragroup conflict, processes, tasks to be carried out, relationships, as well as perceptions and individual personalities facing conflicts. Greer et al. (2008), De Witt et al. (2012) and De Church et al. (2013) defined intragroup conflict as a process that begins when an individual or group perceives differences and opposition between himself and others about interests, resources, beliefs, values or practices. As an example, Pondy (1992) expresses it as a dynamic process in which at least one of the members of the group perceives, feels or behaves against another and defines the conflict as potentially functional, and even neutral, as well as possibly negative. In the same line, the classification by Pondy (1992) and later Jehn $(1994,1997)$ identifies three categories for the intragroup conflict: processes, tasks and relationships. And it has been used by many researchers (O'Neill et al., 2015; De Witt et al., 2012; Smith, 2014; Greer et al., 2008; Jehn et al., 2008; Behfar et al., 2011; Jehn \& Benderesky, 2003; Jehn \& Mannix, 2001; Vodosek, 2007).

De Witt et al. (2013) propose that conflict makes group members more likely to be rigid and to process information partially, using their own information during decision-making, rather than sharing the information with the group. Following this line, Smith (2014) proposes that the presence and persistence of antecedents of conflict lead to a higher level of intragroup conflict, and this level of perceived conflict increases negative behaviors and reduces positive behaviors.
Some studies indicate that group members perceive conflict in a similar way, but that they generally neglect potentially important differences between each of its members (Amason, 1996; Jehn \& Chatman, 2000; Jehn et al., 2010). De Witt et al. (2013) change the concept of intragroup conflict from a homogeneous perception to individual heterogeneous perception. Their studies, with an experimentally controlled population, show that the individual perception of conflict is different among team members.

When the conflict is already a threat, the members of a group seek to confirm their information, as well as the context for their decision-making (Fischer et al., 2011). Mikkelsen and Clegg (2017) add that conflict is an element of dissonance in the order, which can have positive and negative effects. McCarter et al. (2018), in contrast to classifying the conflict as good or bad, focus on identifying five models of intragroup conflict: diversity, behavioral negotiation, social dilemma, social exchange and economy of transaction costs. In particular, they highlight that the models of conflict of diversity and behavioral negotiation (lab) are normally used to analyze conflicts within groups made up of people and have been studied mainly at the individual level within the group, the most widely used methodology being surveys and data from archive ${ }^{1}$.

Jehn and Chatman (2000) suggest that the asymmetry of the personality traits of the members of a group is more important than the conflict itself. This asymmetry of personality traits determines at least the experience of the conflict, this means perceiving the conflict differently, that is, a problem can be perceived as more or less conflictive by the members of a work group. Jehn et al. (2010) include in their studies the individual perception, as well as the attitudes of each of the individuals with the level of conflict, and identified that conflictive people tend to generate more complicated work environments, with less trust, respect, and commitment. In their research, they have found that better attitudes towards the group tend to improve individual satisfaction with it.

1 Other study techniques use the behavioral laboratory, field studies (Van den Assem et al., 2012), longitudinal (Jehn \& Mannix, 2001; Jehn, 1997; Jehn et al., 1999), mixed methods, theory tests of social exchange in a behavioral laboratory (Galinsky et al., 2015). Latest studies based on transaction cost economics laboratory complement years of field studies examining the applicability of the models (Harmon et al., 2015; McDowell \& Voelker, 2008). 
De Witt et al. (2013), when studying the consequences of intragroup conflict, highlight the importance of taking into account the processes at the individual level. They consider that the differences in perception at the individual level about a conflict affects the way in which group members face the conflict and how these affect the way decisions are made (De Dreu \& Weingart, 2003; De Witt et al., 2013).

Rahim (1983) proposes that the five traits of the Big Five Theory can predict the conflict management style (or CMS) ${ }^{2}$. Rispens et al. (2020) conceptualized CMS at the individual level and defined it as the way of each person to approach the conflict; this tendency can direct the feelings, thoughts and actions of an individual towards the conflict, although people usually have a style of conflict management, this could vary according to some situation. According to the Dual concert theory, the CMS is a function that involves a person in himself and others. From this idea four styles of CMS can be understood: forcing, which implies a great personal concern and little for the other person, so it could be cheating, persuasive in excess, great concern for himself and another person, in this case he would be a problem solver looking for satisfactory solutions for both parties, taking great care of others and little of himself would be yielding, little concern for himself and others, he would tend to avoid conflict, for example, by reducing the importance of the subject, and the fifth is the compromise, intermediate concern for himself and another person.

Big Five Theory (Norman, 1963) identifies five personality traits that influence team behavior, namely, openness to experience, responsibility, extroversion, kindness, and neuroticism.

According to Barrick and Mount (1991):

a) openness to experience is associated with being imaginative, creative, open-minded, curious and artistically sensitive;

b) responsibility is associated with hard work, focus on results and organization, with strength of will; c) extraversion is associated with sociability, community life, communicativeness, assertiveness;

d) kindness is associated with courtesy, flexibility, confidence, being cooperative, tolerant, and easygoing; and

e) neuroticism is associated with anxiety, anger, depression, shame, worry, and insecurity.

Teherani and Yamini (2020, p. 2), in their meta-analysis about the connection of personality dimensions and the five styles of conflict resolution, define that "the inconsistent empirical outcomes attest that the conclusive results are still an open question".

Jehn et al. (2010), De Witt et al. (2012) and Vodosek (2007) explain that the process conflict occurs specifically on the logistics of task fulfillment, such as the delegation of tasks and responsibilities.

According to Greer et al. (2008), the process conflict occurs mainly at the beginning of the group's life, and leaving it unresolved is like perpetuating it over time. Jehn et al. (2010) consider the process conflict as disagreements between the assignment of tasks and resources. They represent how well a group manages the logistical support of the strategy and the support of people. According to Greer et al. (2008), the process conflict is especially related to the emotional state of the team members, as well as to the personal connotation of value and respect, suggesting that it has a negative impact on the results of the groups partly as it increases the emotionality of the team members and decreases the ability to focus on the task.

In the specialized literature, three different perceptible scopes are presented within the definitions of the task conflict:

a) De Witt et al. (2012), Lê and Jarzabkowski (2015) and Vodosek (2007) define it as disagreement regarding the contents and results of the task to be carried out, and the relevance of what needs to be accomplished, specifically the goals. For example, Smith (2014) finds that

2 CMS stands for Conflict Management Style. 
$70 \%$ of people perceive a conflict with their functional goals.

b) Jehn et al. (2008) define it as a difference of opinion about how a group task should be performed. Textually, Jehn and Mannix (2001) define it as "...differences of opinion about the work being done and about ideas", and later Mikkelsen and Clegg (2017) - "differences in views, ideas and opinions".

c) De Dreu and Weingart (2003) and Parayitam et al. (2010) define it as disagreements about the right choices or differences of opinion about the decision.

Two possible results can be produced from the task conflict, both divergent; the first is positive, since it increases the understanding and commitment to the task, from the meeting and synthesis between multiple perspectives (O'Neill et al., 2015; Amason, 1996; Parayitam and Dooley, 2007); and the second is negative, since it could distract team members and affect performance (Greer et al., 2008).

Jehn and Mannix (2001) and Jehn et al. (2008) consider relationship conflict as interpersonal disagreements and incompatibilities that include affective components such as feelings of tension and friction. Relationship conflict involves personal issues like dislike, aversion and feelings like annoyance, frustration, and irritation.

De Witt et al. (2012) define relationship conflict as disagreements among team members about interpersonal issues such as personal differences or differences in values and norms. Sometimes this conflict, consistent with affective and cognitive categorization, could be given by aspects such as social events, gossip, dress, political positions (Amason, 1996; Pinkley, 1990).

According to De Dreu and Weingart (2003) and for Greer et al. (2008), relationship conflicts hinder group's performance and member's satisfaction, which can be explained since this kind of conflict increases emotionality within the team and distracts members from the task. Relationship conflict prevents good understanding and good desires among team members and makes group members less open to ideas other members might have about task-related ideas. Relationship conflict develops in terms of misattribution, harsh and emotional language in arguments, or hurtful and aggressive tactics by some group members to convince others of their views (Jehn, 1997).

The aim of this study is to demonstrate the existence of a different element named Structured personal conflict. It is an individual and personal profile, endogenous, latent to the person, and can be distinguished from traditionally studied conflicts of process, task and relationships, which allows a better explanation of intragroup conflict.

\subsection{Research hypotheses}

In a meta-analysis on 116 articles, De Witt et al. (2012) calculated direct correlations between conflict of results and conflict of processes at 0.660 (DS $=0.28)$, relationship conflict and conflict of process at $0.670(D S=0.15)$, and conflict of results and relationship conflict at 0.520 (DS $=0.32$ ). It is significant to underline that inter-construct correlations higher than 0.7 indicate the existence of some degree of multicollinearity that might suggest the elimination of some of the typical constructs for any multivariate analysis (Gujarati, 1993). This study is aimed at exploring the presence of a structured personal conflict within intragroup conflicts, based on the following hypotheses:

H1: The component of structured personal conflict explains a higher percentage of total variance than the component conflict of net processes, net results and net relationships individually.

H2: The components of structured personal conflict, net processes, net results and net relationships build a robust model to explain the phenomenon of intra-group conflict.

Figure 1 presents a conceptual diagram of the investigation.

Although personality significantly helps determine interpersonal interactions (Barrick et al., 2005), personality traits often fail to find a meaningful place in empirical studies (Hogan \& Kaiser, 2005), so their research, unlike others on the sub- 
Traditional Individual Components Intragroup conflict
Proposed Individual Components Intragroup conflict
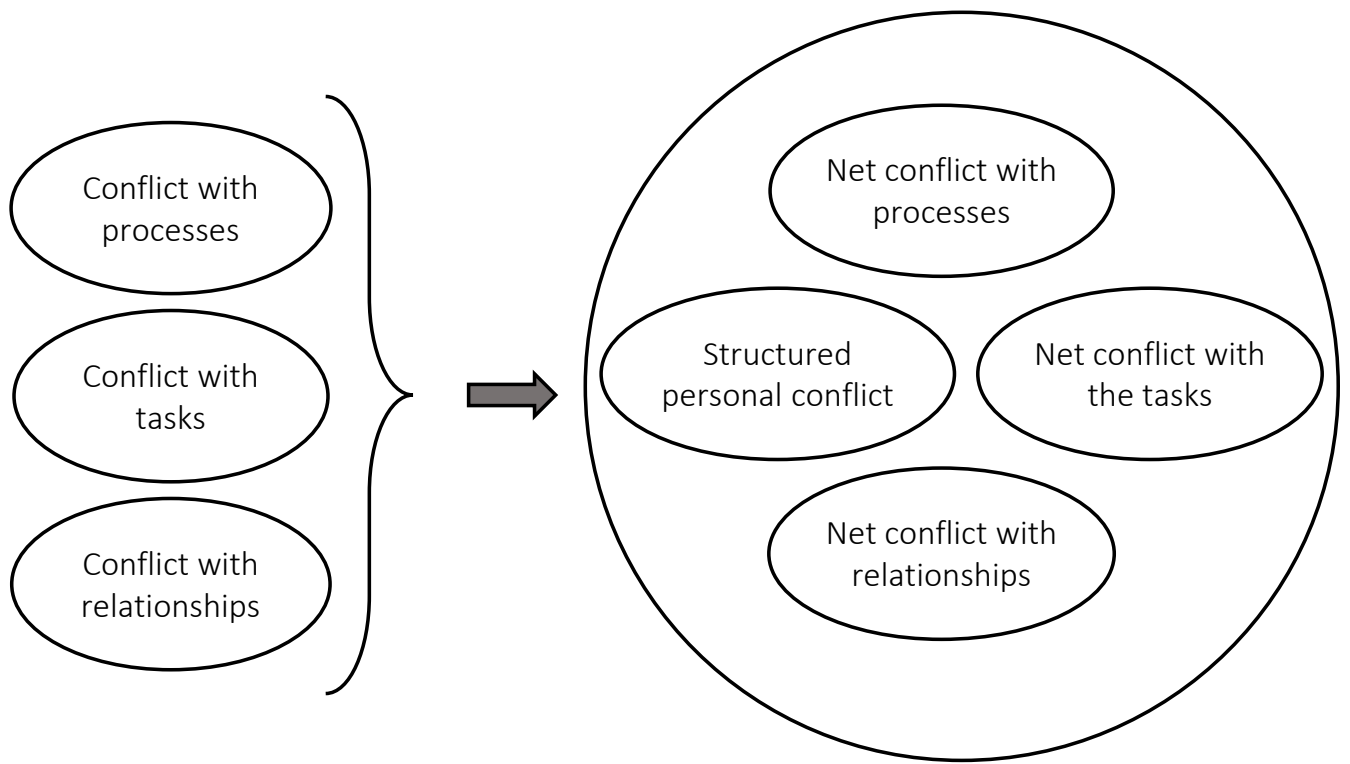

Figure 1. Conceptual diagram of the components that make up the intragroup conflict

ject, focus on the exogenous perception of the person around the conflict of processes, results and relationships, or are justified from the findings that serve to determine how their members work together (Amason \& Schweiger, 1994; Jehn, 1995). The research seeks to contribute to the literature on an endogenous personal profile of conflict that affects the team.

\section{METHOD}

The method consists of five stages:

1) Constructing a research instrument in Spanish.

2) Sample.

3) Internal reliability tests.

4) External reliability.

5) Confirmatory factor analysis.

\subsection{Research instrument}

Following the recommendation of Bostwick and Kyte (2005), the instrument begins with a series of neutral questions to locate respondents within the topic. A first open question was to find out the main conflict that the team has at that time. In the second instance, the subjects were asked: a) From which of the following three elements (processes, results or relationships) do you think this conflict began?

b) If you were responsible for solving that conflict, from which of the following three elements (processes, results or relationships) would you start its correction?

To measure the constructs, a series of 18 statements was used (six items per construct). A 5-point Likert scale was used (where 1 means never and 5 always).

To measure the conflict construct with the processes, the items were adapted from Jehn and Mannix (2001), Jehn et al. (2008), and Bendersky and Hays (2012). There were statements such as: "There is disagreement in my team about the process followed to carry out the entrusted activities," and "The members of my team are upset with the way of delegating the activities within it." To measure the conflict construct with the results to be obtained, the items were adapted from Jehn (1994, 1995), Jehn et al. (2008), Behfar et al. (2011), and Bendersky and Hays (2012), including statements such as: "Frequently, the people in my team have different opinions about the results we obtain," and "In my team, we often 
have disagreements about the results of the project we are working on." To measure the conflict with relationship construct, the items were adapted from Jehn (1995), Jehn and Mannix (2001), Jehn et al. (2008), and Bendersky and Hays (2012). Statements were included such as: "In my work team, it is very clear that there are emotional conflicts," and "The members of my team frequently get angry during work."

\subsection{Sample to test the instrument}

More than 400 members of organizations operating in Mexico were surveyed between July 2018 and May 2019. The sample was voluntary and required that the subject was part of a group at that time. A link to answer the survey was sent by e-mail and social networks. The questionnaire was processed by an internet electronic platform with the ability to rotate the questions and process the captured information to avoid errors, following the recommendation (Abella et al., 2010).

\subsection{Internal reliability test results}

The three constructs tested in the sample resulted in adequate internal reliability, with Pearson item-total correlations between 0.638 and 0.840 , and a Cronbach's alpha of 0.8417 to 0.9001 .

The Sampling Adequacy Test gives a KMO value of 0.944 and Bartlett's Sphericity Test a Chi-square of 2037,117 (P-val < 0.001), which indicates that the matrix of 18 items may be subject to factorization.

Exploratory factor analysis confirms that with only three factors, an extracted variance of $62.8 \%$ can be obtained (Table 1), with significant individual loads (Pérez-Gil et al., 2000).

Applying a VARIMAX rotation, it is achieved that all the items turn out to be significant with individual loads greater than 0.4 within their factor, recommended by Hair et al. (1998). The exception is Item 12, which can be left aside, as the load is slightly below the 0.40 limit. However, it was decided to maintain it, since Cronbach's alpha does not improve substantially with its omission, and the structure of six items per construct would be broken.
Table 1. Component analysis factor matrix

\begin{tabular}{|c|c|c|c|c|}
\hline Item & $\begin{array}{c}\text { Factor } \\
1\end{array}$ & $\begin{array}{c}\text { Factor } \\
2\end{array}$ & Factor 3 & $\begin{array}{c}\text { Shared } \\
\text { variance }\end{array}$ \\
\hline Q13 & 0.674 & - & - & 0.637 \\
\hline Q14 & 0.785 & - & - & 0.702 \\
\hline Q15 & 0.739 & - & - & 0.658 \\
\hline Q16 & 0.667 & - & - & 0.687 \\
\hline Q17 & 0.803 & - & - & 0.705 \\
\hline Q18 & 0.636 & - & - & 0.69 \\
\hline Q1 & - & -0.725 & - & 0.702 \\
\hline Q2 & - & -0.684 & - & 0.614 \\
\hline Q3 & - & -0.678 & - & 0.511 \\
\hline Q4 & - & -0.584 & - & 0.551 \\
\hline Q5 & - & -0.731 & - & 0.682 \\
\hline Q6 & - & -0.774 & - & 0.674 \\
\hline Q7 & - & - & 0.803 & 0.681 \\
\hline Q8 & - & - & 0.641 & 0.588 \\
\hline Q9 & - & - & 0.694 & 0.579 \\
\hline Q10 & - & - & 0.626 & 0.613 \\
\hline Q11 & - & - & 0.648 & 0.687 \\
\hline Q12 & - & - & 0.398 & 0.339 \\
\hline $\begin{array}{l}\text { Variance } \\
\text { extracted }\end{array}$ & 4.0713 & 3.9493 & 3.2797 & 11.3003 \\
\hline $\begin{array}{l}\% \text { about } \\
\text { total }\end{array}$ & $22.6 \%$ & $21.9 \%$ & $18.2 \%$ & $62.8 \%$ \\
\hline
\end{tabular}

Note: The rotation is Varimax of the factor loads.

\subsection{External reliability}

The discriminant validity of Fornell and Larcker (1981) was adequate as the square roots of the average variance extracted of each factor were superior to the pairwise correlations against the other factors.

\subsection{Confirmatory Factor Analysis (CFA)}

When applying a CFA to the sample information, to check the grouping of the 18 items within their corresponding theoretical factors, and using the LISREL 10.1 (64 Bit) system with Maximum Likelihood estimators, it was found that the indicators of goodness-of-fit tests were marginally acceptable, according to the following results (Hair et al., 1998, p. 687):

1) All the coefficients of the items individually are relevant and significant to their theoretical construct $\left(\mathrm{R}^{2}>0.25\right.$ and a $\mathrm{P}$-val $\left.<0.001\right)$.

2) The mean square error of approximation RMSEA $=0.0825$ with a $90 \%$ CI of $(0.0707$; 
Table 2. Correlation matrix of information grouped by theoretical construct

\begin{tabular}{|c|c|c|c|}
\hline Theoretical construct & Process & Task & Relationship \\
\hline Process & 0.834 & - & - \\
\hline Task & $0.680 * *$ & 0.797 & - \\
\hline Relationship & $0.682 * *$ & $0.705^{* *}$ & 0.847 \\
\hline
\end{tabular}

Note: The diagonal of each factor presents the square root of the AVE. ** - significant correlations at the 0.01 level.

0.0943) is marginally acceptable (what is applicable is an index between 0.05 and 0.08 ).

3) The chi-square likelihood ratio statistic $(\mathrm{C} 1)=$ 312,391 (P-val $<0.001$ ) is marginally acceptable (what is applicable is $\mathrm{P}$-val >0.05).

4) The standardized fit index NFI $=0.883$ is marginally acceptable (what is applicable is NFI > 0.9).

5) The Tucker-Lewis index NNFI $=0.917$ is acceptable (what is applicable is NNFI $>0.9$ ).

\section{RESULTS}

\subsection{Sample data descriptive}

The composition of the sample (201 generated) was as follows: 122 men (60.7\%), 77 women $(38.3 \%)$, and two did not declare; the average age was 34.8 years (SD of 11.0); 39 (19.4\%) graduated from high school; graduates 90 (44.8\%) and postgraduates $72(35.8 \%)$. On average, team members - 13.3 (with a SD of 19.7), they have an average age in their teams 4.1 years (SD of $4.2), 123$ declared to be team leaders (61.2\%) and 78 followers (38.8\%). Types of respondents' activities in the company in which they work: Financial 44 (21.9\%); Academic 41 (20.4\%), and Commercial and Marketing 14 (7.0\%).

\subsection{Correlations matrix}

Direct correlations between outcome conflict and process conflict is $\mathrm{r}=0.680(\mathrm{PV}<0.05)$ and relationship conflict and process conflict is $r=0.682$
(PV < 0.05); the correlation between outcome conflict and relationship conflict is $\mathrm{r}=0.705$ ( $\mathrm{P}$-val $>$ $0.05)^{3}$. This presupposes a problem of multicollinearity. Table 2 presents the respective inter-construct correlations.

\subsection{Test hypothesis 1}

In particular, to address this situation, Gujarati (1993) suggests applying the latent variable - factorization process. For this reason, this investigation proposes to explore the existence of the fourth construct that can be created from the information of the three traditional theoretical constructs.

To test hypothesis 1, the Principal Component Analysis (PCA) of the LISREL 10.1 System (64 Bit) methodology is used ${ }^{4}$. Table 3 presents the first six latent components constructed based on the information from the 201 useful questionnaires.

To illustrate the theoretical composition of the first three main components, Figure 2 shows the average loads of items per construct with reference to their theoretical origins.

The first component (PC1) is constructed from the items of the process conflict (with an average of loads of 0.23 ), results (with 0.22) and relationships (with 0.25 ). This practically uniform composition verifies the existence of a component (endogenous) that explains the high correlation observed in the correlation matrix. This PC1 component, for the present investigation, will be called Structured Personal Conflict (SPC), as an extension of the works that explain that personality differences can be a major reason for conflict, as well as the perception of conflict and preference for managing that conflict.

3 According to Nieves and Dominguez (2010), a strong positive and significant correlation is $\mathrm{r}>0.7$ and $\mathrm{P}$-val $<0.01$.

4 It is used to form a smaller number of uncorrelated variables from a large data set. The objective of principal component analysis is to explain the maximum amount of variation with the fewest components. This analysis is commonly used in the social sciences when using large data sets. It is commonly used as a step in a series of analyses to reduce the number of variables and avoid multicollinearity (MINITAB Note). 
Table 3. Principal components analysis

\begin{tabular}{|c|c|c|c|c|c|c|c|}
\hline & ent & PC_1 & PC_2 & PC_3 & PC_4 & PC_5 & PC_6 \\
\hline Eigen value & \multirow{4}{*}{$\begin{array}{c}\text { Theoretical origin of } \\
\text { the item }\end{array}$} & 9.73 & 1.31 & 1.17 & 0.77 & 0.68 & 0.58 \\
\hline SD & & 0.97 & 0.13 & 0.12 & 0.08 & 0.07 & 0.06 \\
\hline$\%$ of variance & & 54.08 & 7.29 & 6.49 & 4.29 & 3.78 & 3.24 \\
\hline$\%$ accumulated & & 54.08 & 61.37 & 67.86 & 72.14 & 75.92 & 79.17 \\
\hline Q1 & \multirow{6}{*}{ Process } & 0.25 & 0.206 & -0.255 & -0.178 & -0.323 & 0.087 \\
\hline Q2 & & 0.238 & 0.223 & -0.163 & -0.145 & -0.381 & 0.124 \\
\hline Q3 & & 0.188 & 0.379 & -0.091 & 0.302 & 0.579 & 0.341 \\
\hline Q4 & & 0.237 & 0.189 & -0.058 & -0.223 & 0.381 & -0.211 \\
\hline Q5 & & 0.248 & 0.266 & -0.17 & 0.126 & -0.122 & -0.056 \\
\hline Q6 & & 0.226 & 0.367 & -0.202 & -0.017 & -0.009 & -0.368 \\
\hline Q7 & \multirow{6}{*}{ Task } & 0.196 & -0.02 & 0.551 & -0.237 & -0.033 & -0.392 \\
\hline Q8 & & 0.229 & 0.088 & 0.306 & -0.249 & 0.054 & -0.016 \\
\hline Q9 & & 0.215 & 0.006 & 0.397 & 0.128 & -0.167 & 0.33 \\
\hline Q10 & & 0.245 & -0.046 & 0.259 & 0.103 & -0.008 & 0.463 \\
\hline Q11 & & 0.254 & 0.143 & 0.264 & -0.052 & -0.02 & -0.001 \\
\hline Q12 & & 0.19 & -0.086 & 0.119 & 0.768 & -0.112 & -0.398 \\
\hline Q13 & \multirow{6}{*}{ Relationship } & 0.253 & -0.201 & -0.148 & 0.1 & -0.258 & 0.142 \\
\hline Q14 & & 0.237 & -0.363 & -0.18 & -0.181 & 0.124 & 0.042 \\
\hline Q15 & & 0.237 & -0.355 & -0.04 & -0.087 & 0.295 & 0.02 \\
\hline Q16 & & 0.266 & -0.187 & -0.1 & -0.005 & 0.191 & -0.131 \\
\hline Q17 & & 0.238 & -0.366 & -0.211 & 0.044 & -0.027 & -0.057 \\
\hline Q18 & & 0.274 & -0.135 & -0.105 & -0.018 & -0.056 & 0.006 \\
\hline
\end{tabular}

Note: SD stands for standard deviation.

The second component is mainly loaded with items related to the process conflict (with 0.27 ), which is attenuated by the items related to the relationship conflict (with 0.27 but with a negative sign). The third component is mainly loaded by the items related to the outcome conflict (with 0.32), which is attenuated by the items related to the other two types of conflict.
Table 3 shows that the first component (PC1) reaches an Eigen value of 9.73 (DS $=0.94$ ), which represents by itself $54.08 \%$ of the total variance. This value is significantly removed from the Eigen values of the other constructs. In the absence of an intersection between the confidence interval of the Eigen value of component 1 and the sum of the Eigen values of the following three, hypothesis 1 is approved.

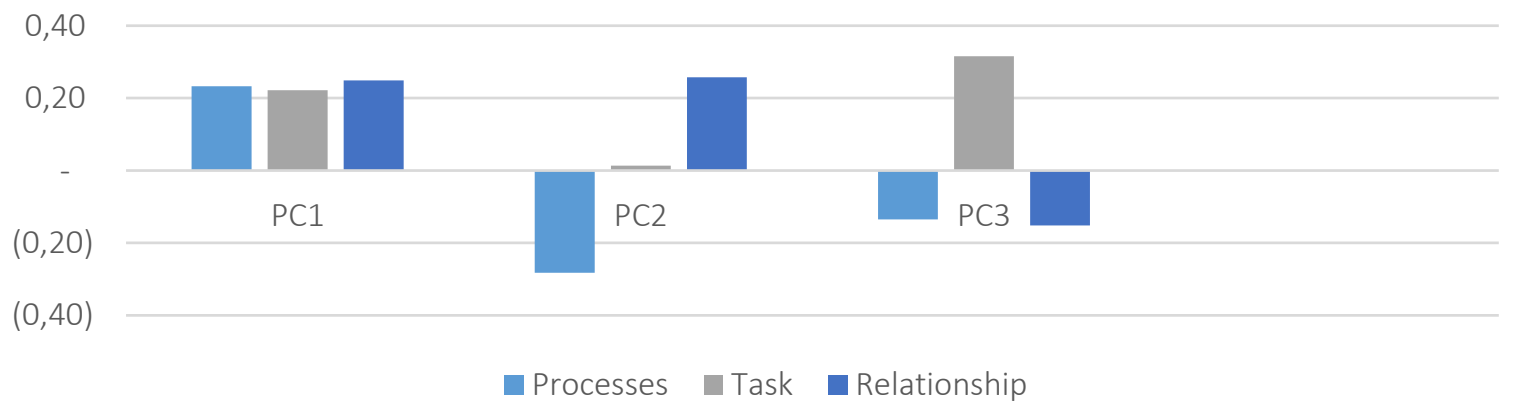

Figure 2. Theoretical composition of the first three main components 


\subsection{Test hypothesis 2}

To test hypothesis 2, it is proposed to use Confirmatory Factor Analysis (CFA) to evaluate four rival models composed of different quantification options of the Structured Personal Conflict (SPC) construct.

- Model 1: SPC = simple average of 18 items.

- Model 2: SPC = weighted average of 18 items based on the ACP coefficients for the first component PC1.

- Model 3: SPC = value of the item with the lowest score.

- Model 4: SPC = value of the first quartile of 18 items.

To quantify the Net conflict process, Net conflict task and Net conflict relationship constructs, the average of the respective items will be used, subtracting from each of them the value of the structured personal conflict (SPC), depending on the model.

In accordance with the recommendations of Hair et al. (1998), to locate the best model, the various goodness-of-fit tests obtained from the Confirmatory Factor Analysis (CFA) are com- pared through the LISREL 10.1 system (64 Bit) with estimators of Maximum Likelihood. The results of the goodness-of-fit tests of the four models are presented in Table 4.

Model 3 is the one that obtains the best scores in the goodness-of-fit tests, compared to rival models. It only requires the $\mathrm{R}^{2}$ coefficient issue to be resolved.

As an example of operationalizing Model 3, assuming that a team member rates the conflict process construct items in $\{3,4,5,4,4,5\}$, task in $\{5,4,4,4$, $4.5\}$, and relations in $\{3,3,4,4,5,4\}$. The value of the structural personal conflict construct (SPC) is 3 (the value of the item with the lowest score), the value of the Net conflict process is 1.17 (average value of the construct items after subtracting from each of them the value of 3), that of the Net conflict task is 1.33 , and that of Net conflict relations is 0.83 .

However, the model is improved without dispensing with three items with $\mathrm{R}^{2}$ problems $\mathrm{T} 12$, T17 and T3, maintaining five items for each construct: (T12) We often discuss in my team the reasons for doing the projects; (T17) In my team, there are often fights over personal issues; and (T3) My team members disagree with the allocation of resources, one from each construct, to maintain the balance of 5 items per

Table 4. Comparison of goodness-of-fit measures for rival models

\begin{tabular}{|c|c|c|c|c|c|}
\hline Test & Model 1 & Model 2 & Model 3 & Model 4 & Approval rule \\
\hline$R^{2}$ coefficients & $\begin{array}{c}\text { All are } \\
\mathrm{R}^{2}<0.25\end{array}$ & $\begin{array}{c}\text { All are } \\
R^{2}>0.25\end{array}$ & $\begin{array}{c}\text { Only } 16 \text { of } 18 \text { are } R^{2} \\
>0.25\end{array}$ & $\begin{array}{c}\text { Only } 11 \text { of } 18 \text { are } R^{2} \\
>0.25\end{array}$ & $R^{2}>0.25$ \\
\hline P-val coefficients & $\begin{array}{c}\text { All are } \\
\text { P-val }<0.001\end{array}$ & $\begin{array}{c}\text { All are } \\
\text { P-val }<0.001\end{array}$ & $\begin{array}{c}\text { All are } \\
\text { P-val }<0.001\end{array}$ & $\begin{array}{c}\text { All are } \\
\text { P-val }<0.001\end{array}$ & P-val $<0.05$ \\
\hline Conditional number & 113.78 MC present & $\begin{array}{c}8,204.80 \mathrm{MC} \\
\text { present }\end{array}$ & $\begin{array}{l}4.93 \mathrm{MC} \text { do not } \\
\text { present }\end{array}$ & $\begin{array}{l}3.53 \mathrm{MC} \text { do not } \\
\text { present }\end{array}$ & MC do not present \\
\hline Ratio Chi-square (C1) & $\begin{array}{c}256.790 \\
(P-v a l<0.01)\end{array}$ & $\begin{array}{c}257.472 \\
(P-v a l<0.01)\end{array}$ & $\begin{array}{c}248.173 \\
(P-v a l<0.01)\end{array}$ & $\begin{array}{c}250.843 \\
(P-v a l<0.01)\end{array}$ & P-val < 0.05 \\
\hline $\begin{array}{l}\text { Goodness-of-fit index } \\
\text { GFI }\end{array}$ & 0.877 & 0.882 & 0.885 & 0.884 & Greater is better \\
\hline $\begin{array}{l}\text { Quadratic residual } \\
\text { RMSEA }\end{array}$ & 0.0610 & 0.0611 & 0.0585 & 0.0595 & From 0.050 to 0.080 \\
\hline $90 \%$ CI RMSEA & $(0.048 ; 0.073)$ & $(0.049 ; 0.073)$ & $(0.046 ; 0.071)$ & $(0.047 ; 0.072)$ & Not including zero \\
\hline $\begin{array}{l}\text { Comparative fit index } \\
(\mathrm{CFI})\end{array}$ & 0.938 & 0.99 & 0.915 & 0.845 & Greater than 0.9 \\
\hline Net fit index NFI & 0.868 & 0.977 & 0.819 & 0.702 & Greater than 0.9 \\
\hline $\begin{array}{l}\text { Tucker-Lewis Index } \\
\text { (NNFI) }\end{array}$ & 0.928 & 0.988 & 0.902 & 0.819 & Greater than 0.9 \\
\hline
\end{tabular}

Note: MC stands for Multicollinearity. 
construct. The CFA for Model 3, now limited to 15 items, presents the following improvement of goodness-of-fit indicators:

1) All the $R^{2}$ of the coefficients are greater than 0.25 , therefore they are relevant.

2) All the P-values of the coefficients are less than 0.001 , therefore they are significant.

3) The Conditional number 4,547 indicates that there is no multicollinearity.
4) The Chi-square ratio $(\mathrm{Cl})=168,749(\mathrm{P}<0.001)$ declares a marginal acceptability.

5) The goodness of fit index GFI $=0.902$ is adequate.

6) The root mean square RMSEA $=0.0592$ (with a $90 \%$ confidence interval between 0.0435 ; $0.0742)$ is acceptable.

7) Comparative fit index (CFI) $=0.933$, which is acceptable.

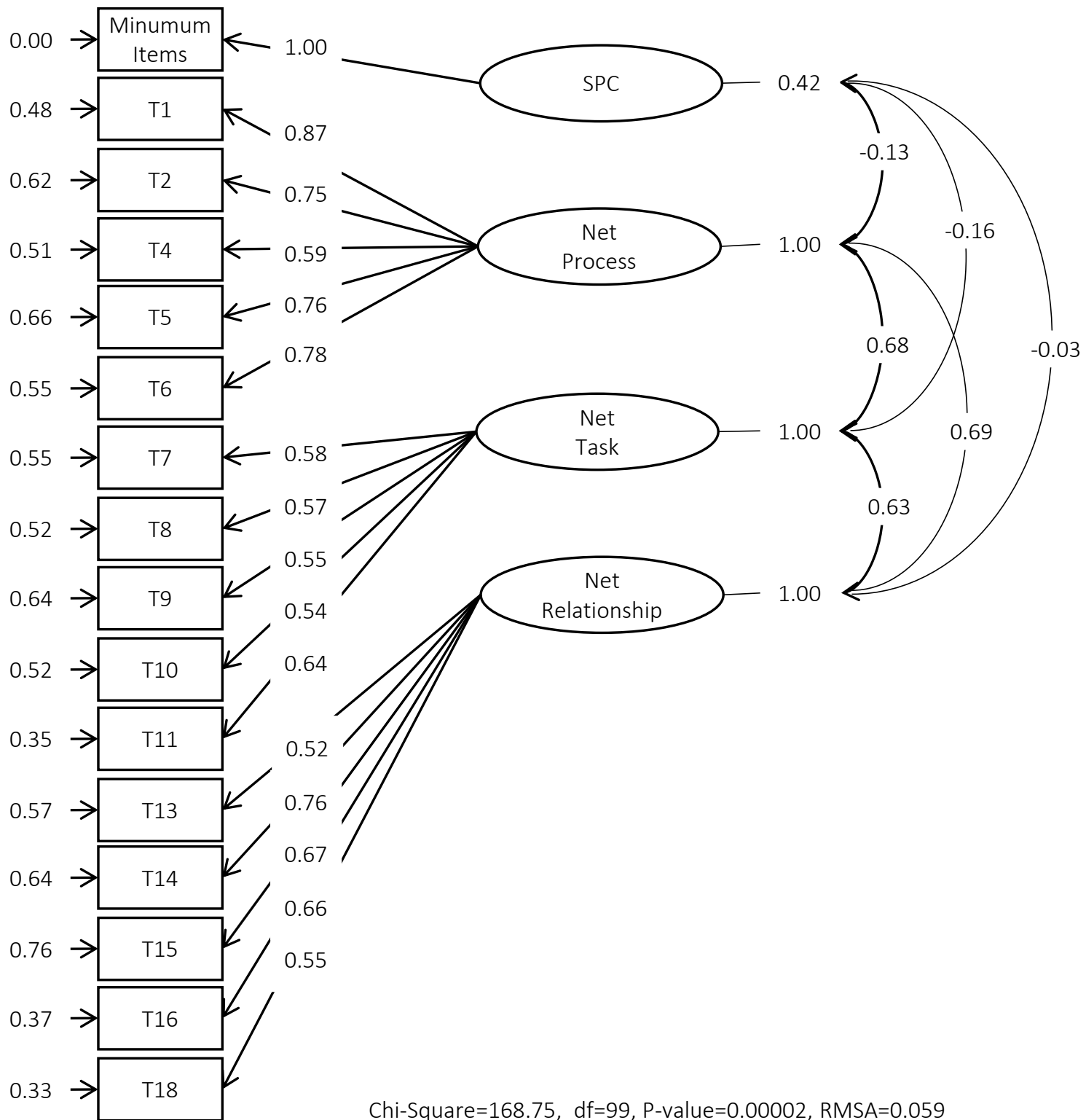

Note: The index of the arrows presents the estimators of the standardized solution.

Figure 3. Variable relationship diagram 
8) The Net fit index NFI $=0.855$ indicates a marginal acceptability.

9) The Tucker-Lewis index, NNFI $=0.919$, indicates an acceptable non-standard fit.

This model shows robust results, which is proven by Hypothesis 2. Figure 3 presents the relationship diagram (Path Diagrams) of the proposed model.

\section{DESCRIPTIVE VALUES OF THE NEW CONSTRUCTS}

Given model 3, Table 5 presents the descriptive statistics of the sample based on the 15 -item instrument.

Table 5. Basic statistics of the sample constructs

\begin{tabular}{l|c:c:c:c}
\hline \multicolumn{1}{c}{ Variable } & N & Mean & $\begin{array}{c}\text { SE } \\
\text { Mean }\end{array}$ & St. dev \\
\hline $\begin{array}{l}\text { Structural Personal } \\
\text { Conflict }\end{array}$ & 201 & 1.493 & 0.049 & 0.694 \\
\hdashline $\begin{array}{l}\text { Net Process Conflict } \\
\text { Net Task Conflict }\end{array}$ & 201 & 1.196 & 0.054 & 0.764 \\
\hline Net Relationship & 201 & 0.980 & 0.045 & 0.632 \\
Conflict & 201 & 0.885 & 0.047 & 0.669 \\
\hline Team members & 201 & 13.3 & 1.390 & 19.650 \\
\hline Years on the team & 201 & 4.1 & 0.3 & 4.2 \\
\hline Age of members & 200 & 34.8 & 0.8 & 11.0 \\
\hline
\end{tabular}

The inter-construct correlations are presented in Table 6. Now, the correlations obtained have less interdependence than those identified under the traditional model (see Table 2).

Table 6. Correlation matrix of the information grouped by theoretical construct

\begin{tabular}{l|c:c:c}
\hline \multicolumn{1}{c}{ Construct } & SPC & $\mathbf{1}$ & $\mathbf{2}$ \\
\hline $\begin{array}{l}\text { 1. Net Process } \\
\text { Conflict }\end{array}$ & $-0.159^{* *}$ & - & - \\
\hdashline 2. Net Task Conflict & $-0.242^{* * *}$ & $0.464^{* * *}$ & - \\
$\begin{array}{l}\text { 3. Net Relationship } \\
\text { Conflict }\end{array}$ & -0.032 & $0.481^{* * *}$ & $0.419^{* * *}$ \\
\hline
\end{tabular}

Note: Significant correlations at the 0.05 level if **, 0.01 if $* * *$.

It is worth noting the negative signs of the correlations between the constructs of conflict in processes, task and relationships, against the structural personal conflict, which suggests that, the greater the personal structural conflict, the less margin to identify any other type of specific conflict, and vice versa. Another significant finding is the degree of independence found between personal structural conflict and conflict with relationships with others.

\section{DISCUSSION}

Personality traits remain a subject of study and have found significant support in empirical studies (Hogan \& Sherman, 2020). Additionally, the literary review recognized about the influence that individual personality traits have on team performance. For example, De Witt et al. (2013) report that intragroup conflict depends on individual perceptions rather than on a collective variable. More recently, Ayub et al. (2017) strongly associate personality traits and performance with interactions between conflicts and their conflict management styles.

A first finding, based on the sample data, was the important correlation by pairs, positive $(0.65>\mathrm{r}>0.70)$ and significant $(\mathrm{P}$-val $<0.01)$, between the constructs of results and relationship processes. This result is similar to the meta-analysis on 116 articles prepared by De Witt et al. (2012), except for the correlation between the conflict of results and the conflict of relationship, which in this study with the Mexican sample was substantially higher than that of the meta-analysis $(0.705>0.52$, $\mathrm{P}$-val $>0.05)$. This indicates an important component of multicollinearity. These correlations greater than 0.7 between pairs of regresses are a symptom of multicollinearity. Gujarati (1993) suggests, as a remedial measure, to omit some constructs that would go against the theories reviewed in the literature. A second remedial measure is to apply a latent variable factorization process.

From a Confirmatory Factor Analysis, four rival models were analyzed to quantify the structured personal conflict construct (SPC). The model that presented the best goodness-of-fit statistics was the one to quantify the structured personal conflict construct (SPC), based on the item with the lowest score, out of the 15 used. This model has the advantage of offering a series of constructs to measure intragroup conflicts with lower inter-construct correlations than is presented in the meta-analysis of 116 articles prepared by De Witt et al. (2012), recommended situation for multivariable analysis models. 


\section{CONCLUSION}

According to Hypothesis 1, this study provides evidence on the existence of a personal profile, which is present in intragroup conflicts and can be distinguished from the conflicts of processes, task, and relationships, traditionally studied by Pondy (1992) and Jehn (1994 1997). Particularly, using the Principal Component Analysis, the existence of a first component (PC1), which consists of items of the process conflict (with an average of loads of 0.23), tasks (with 0.22) and relationships (with 0.25), the existence of a component (endogenous) that explains the high correlation observed in the correlation matrix is verified. This PC1 identified a construct, Structured Personal Conflict (SPC), which is in line with the asymmetry of the personality traits of group members in conflict issues already found by Jehn and Chatman (2000) and Jehn et al. (2010).

Model 3 presents robust results, which is supported by Hypothesis 2. The model uses the value of the item with the lowest score to quantify the Structured Personal Conflict (SPC), and the average of the respective items minus the item with the lowest commented score to quantify each of the Net Conflict process, Net Conflict task and Net Conflict relationship constructs, it is the one that obtains the best scores in the goodness-of-fit tests than rival models.

An additional finding was the final instrument, which was found to be reliable and valid across various tests that yielded satisfactory results.

For management, it is important to highlight the importance of identifying structured personal conflict in the selection process and in terms of the performance measures of teams.

\section{AUTHOR CONTRIBUTIONS}

Conceptualization: Luis Llanos, Fernando Granados.

Data curation: Luis Llanos.

Formal analysis: Luis Llanos.

Investigation: Luis Llanos, Fernando Granados.

Methodology: Luis Llanos.

Project administration: Fernando Granados.

Software: Fernando Granados.

Supervision: Fernando Granados.

Validation: Fernando Granados.

Visualization: Luis Llanos.

Writing - original draft: Luis Llanos, Fernando Granados.

Writing - review \& editing: Luis Llanos, Fernando Granados.

\section{REFERENCES}

1. Abella, C., Rodríguez, D., \& Pérez-Sindín, X. (2010). Efectos del cambio de orden de variables y categorías de respuesta en los resultados de una encuesta política. (Effects of changing the order of variables and response categories on the results of a political survey). Metodología de Encuestas, 12, 7-27. Retrieved from http://casus.usal.es/pkp/index.php/MdE/article/view/1000
2. Amason, A. C. (1996). Distinguishing the effects of functional and dysfunctional conflict on strategic decision-making: Resolving a paradox for top management teams. Academy of Management Journal, 39(1), 123-148. Retrieved from https://www.jstor.org/stable/256633

3. Amason, A. C., \& Schweiger, D. M. (1994). Resolving the Paradox of Conflict, Strategic Decision Making, and Organizational Performance. International Journal of Conflict Management, 5(3), 239-253. https:// doi.org/10.1108/eb022745

4. Ayub, N., AlQurashi, S., Al-Yafi, W., \& Jehn, K. (2017). Personality traits and conflict management styles in predicting job performance and conflict. International Journal of Conflict Management, 28(5), 671-694. https://doi.org/10.1108/ ijcma-12-2016-0105 
5. Barrick, M. R., \& Mount, M. K. (1991). The Big Five Personality Dimensions and Job Performance: A Meta-analysis. Personnel Psychology, 44(1), 1-26. https:// doi.org/10.1111/j.1744-6570.1991. tb00688.x

6. Barrick, M. R., Parks, L., \& Mount, M. K. (2005). Self-Monitoring as a Moderator of the Relationships Between Personality Traits and Performance. Personnel Psychology, 58(3), 745-767. https://doi.org/10.1111/ j.1744-6570.2005.00716.x

7. Behfar, K. J., Mannix, E. A., Peterson, R. S., \& Trochim, W. M. (2011). Conflict in Small Groups: The Meaning and Consequences of Process Conflict. Small Group Research, 42(2), 127-176. https://doi. org/10.1177/1046496410389194

8. Bendersky, C., \& Hays, N. A. (2012). Status Conflict in Groups. Organizations Science, 23(2), 299-596. https:// doi.org/10.1287/orsc.1110.0734

9. Bostwick, G.J., \&. Kyte, N.S. (2005). Measurement. In R. M. Grinnell, \& Y. A. Unrau (Eds.), Measurement Social Work: Research and Evaluation Quantitative and Qualitative Approach. (pp. 97-111). New York: Oxford University Press.

10. Carretero-Dios, H., \& Pérez, C. (2007). Normas para el desarrollo y revisión de estudios instrumentales: consideraciones sobre la selección de tests en la investigación psicológica. (Guidelines for the development and review of instrumental studies: considerations on the selection of tests in psychological research). International Journal of Clinical and Health Psychology, 7(3), 863-882. Retrieved from http:// www.aepc.es/ijchp/NDREI07_ es.pdf

11. De Church, L. A., Mesmer-Magnus, J. R., \& Doty, D. (2013). Moving beyond relationship and task conflict: Toward a process-state perspective. Journal of Applied Psychology, 98(4), 559-578. https://doi.org/10.1037/ a0032896

12. De Dreu, C.K.W., \& Weingart, L.R. (2003). Task versus relationship conflict, team performance, and team member satisfaction: A meta-analysis. Journal of Applied Psychology, 88(4), 741-749. https:// doi.org/10.1037/0021-9010.88.4.741
13. De Wit, F.R.C., Jehn, K.A., \& Scheepers, D. (2013), Task conflict, information processing, and decision making: The damaging effect of relationship conflict. Organizational Behavior and Human Decision Process, 122(2), 177-189. https://doi. org/10.1016/j.obhdp.2013.07.002

14. De Witt, F.R.C., Greer, L.L., \& Jehn, K.A. (2012). The Paradox of Intragroup Conflict: A Meta-Analysis. Journal of Applied Psychology, 97(2), 360-390. https://doi.org/10.1037/ a0024844

15. Fischer, P., Kastenmüller, A., Greitemeyer, T., Fischer, J., Frey, D., \& Crelley, D. (2011). Threat and selective exposure: The moderating role of threat and decision context on confirmatory information search after decisions. Journal of Experimental Psychology: General, 140(1), 51-62. https://doi.org/10.1037/ a0021595

16. Fornell, C., \& Larcker, D. F. (1981). Evaluating Structural Equation Models with Unobservable Variables and Measurement Error. Journal of Marketing Research, 18(1), 39-50. https://doi. org/10.1177/002224378101800104

17. Galinsky, A. D., Rucker, D. D., \& Magee, J. C. (2015). Power: past findings, present considerations, and future directions. In M. Mikulincer, P. R. Shaver, J. A. Simpson, J. F. Dovidio (Eds.), APA Handbook of Personality and Social Psychology (pp. 421-460). Washington D.C: American Psychological Association. https://doi.org/10.1037/14344-016

18. George, D., \& Mallery, P. (2003). SPSS for Windows step by step: A Simple Guide and Reference. Boston: Allyn \& Bacon.

19. Greer, L. L., Jehn, K. A., \& Mannix, E. A. (2008). Conflict Transformation A Longitudinal Investigation of the Relationships Between Different Types of Intragroup Conflict and the Moderating Role of Conflict Resolution. Small Group Research, 39(3), 278-302. https://doi. org/10.1177/1046496408317793

20. Gujarati, D. N. (1993). Econometría [Econometrics]. Ciudad de México: McGraw Hill.

21. Hair, J., Anderson, R., Tatham, R., \& Black, W. (1998). Multivariate data analysis. New Jersey: Prentice Hall.
22. Harmon, D., Kim, P. H., \& Mayer, K. J. (2015). Breaking the letter vs. spirit of the law: How the interpretation of contract violations affects trust and the management of relationships. Strategic Management Journal, 36(4), 497-517. https://doi. org/10.1002/smj.2231

23. Hogan, R., \& Kaiser, R. B. (2005). What we know about Leadership. Review of General Psychology, 9(2), 169-180. https://doi. org/10.1037/1089-2680.9.2.169

24. Hogan, R., \& Sherman, R. A. (2020). Personality theory and the nature of human nature. Personality and Individual Differences, 152(1), 109561. https://doi.org/10.1016/j. paid.2019.109561

25. Hu, L., \& Bentler, P. M. (1995). Evaluating model fit. In R. H. Hoyle (Ed.), Structural equation modeling: Concepts, issues, and application (pp. 76-99). Thousand Oak: Sage Publications.

26. Hu, L., \& Bentler, P. M. (1999). Cutoff criteria for fit indexes in covariance structure analysis: Conventional versus new alternatives. Structural Equation Modeling: A Multidisciplinary Journal, 6(1), 1-55. https://doi. org/10.1080/10705519909540118

27. Jehn, K. A. (1994). Enhancing Effectiveness: An Investigation of Advantages and Disadvantages of Value-Based Intragroup Conflict. International Journal of Conflict Management, 5(3), 223-238. https:// doi.org/10.1108/eb022744

28. Jehn, K. A. (1995). A Multimethod Examination of the Benefits and Detriments of Intragroup Conflict. Administrative Science Quarterly, 40(2), 256-282. https://doi. org/10.2307/2393638

29. Jehn, K. A. (1997). A Qualitative Analysis of Conflict Types and Dimensions in Organizational Groups. Administrative Science Quarterly, 42(3), 530-557. https:// doi.org/10.2307/2393737

30. Jehn, K. A., \& Benderesky. C. (2003). Intragroup conflict in organizations: a contingence perspective on the conflict-outcome relationship. Research in Organizational Behavior, 
25, 187-242. https://doi.org/10.1016/ s0191-3085(03)25005-X

31. Jehn, K. A., \& Chatman, J. A. (2000). The influence of proportional and perceptual conflict composition on team performance. The International Journal of Conflict Management, 11(1), 56-73. https://doi. org/10.1108/eb022835

32. Jehn, K. A., \& Mannix, E. A. (2001) The Dynamic Nature of Conflict: A Longitudinal Study of Intragroup Conflict and Group Performance. Academy of Management Journal, 44(2), 238-251. https://doi. org/10.5465/3069453

33. Jehn, K. A., Greer, L., Levine, S., \& Sulanski, G. (2008). The Effects of Conflict Types, Dimensions, and Emergent States on Group Outcomes. Group Decision and Negotiation, 17(6), 465-49. https://doi. org/10.1007/s10726-008-9107-0

34. Jehn, K. A., Northcraft, G. B., \& Neale, M. A. (1999). Why Differences Make a Difference: A Field Study of Diversity, Conflict and Performance in Workgroups. Administrative Science Quarterly, 44(4), 741-763. https://doi. org/10.2307/2667054

35. Jehn, K. A., Rispens, S., \& Thatcher, S. M. B. (2010). The effects of conflict asymmetry on workgroup and individual outcomes. Academy of Management Journal, 53(3), 596-616. https://doi.org/10.5465/ amj.2010.51468978

36. Lê, J. K., \& Jarzabkowski, P. A. (2015). The Role of Task and Process Conflict in Strategizing. British Journal of Management, 26(3), 439462. https://doi.org/10.1111/14678551.12076

37. McCarter, M., Wade-Benzoni, K., Fudge Kamal, D., Min Bang, H., Hyde, S., \& Maredia, R. (2018). Models of Intragroup Conflict in Management: A Literature Review. Journal of Economic Behavior and Organization, 178, 925-946. https:// doi.org/10.1016/j.jebo.2018.04.017

38. McDowell, W., \& Voelker, T. (2008). Information, resources and transaction cost economics: the effects of informal network centrality on teams and team performance. Institute of Behavioral and Applied
Management, 9(2), 134-147. https:// doi.org/10.21818/001c.17121

39. Mikkelsen, E. N., \& Clegg, S. (2017). Conceptions of Conflict in Organizational Conflict Research: Toward Critical Reflexivity. Journal of Management Inquiry, 28(2), 166-179. https://doi org/10.1177/1056492617716774

40. Muñiz, J., Elosua, P., \& Hambleton, R. K. (2013). Directrices para la traducción y adaptación de los tests. (Guidelines for the translation and adaptation of tests). Psicothemaapeles del Psicólogo, 25(2), 151-157. https://doi.org/10.7334/ psicothema2013.24

41. Nieves, H. A., \& Domínguez, S. F. (2010). Probabilidad y estadística: un enfoque moderno. (Probability and Statistics: a Modern Approach). Ciudad de México: McGraw Hill.

42. Norman, W. T. (1963). Toward an adequate taxonomy of personality attributes: Replicated factor structure in peer nomination personality ratings. The Journal of Abnormal and Social Psychology, 66(6), 574-583. https://doi.org/10.1037/ h0040291

43. Nunnally, J. C., \& Bernstein, I. H. (1995). Teoría Psicométrica [Psychometric Theory]. Ciudad de México: McGraw Hill.

44. O’Neill, T. A., McLarnon, M. J. W., Hoffart, G. C., Woodley, H. J. R., \& Allen, N. J. (2015). The Structure and Function of Team Conflict State Profiles. Journal of Management, 44(2), 811-836. https://doi. org/10.1177/0149206315581662

45. Parayitam, S., \& Dooley, R. S. (2007). The relationship between conflict and decision outcomes: Moderating effects of cognitiveand affect based trust in strategic decision-making teams. International Journal of Conflict Management, 18(1), 42-73. https://doi. org/10.1108/10444060710759318

46. Parayitam, S., Olson, B. J., \& Bao, Y. (2010). Task conflict, relationship conflict and agreement seeking in Chinese top management teams. International Journal of Conflict Management, 21(1), 94-116. https://doi. org/10.1108/10444061011016641
47. Pérez-Gil, J. A., Chacón, S., \& Moreno, R. (2000). Validez de constructo: el uso de análisis factorial exploratorio-confirmatorio para obtener evidencias de validez [Construct validity: the use of exploratory-confirmatory factor analysis to obtain evidence of validity]. Psicothema, 12(2), 442-446. Retrieved from http://www.psicothema.com/pdf/601.pdf

48. Pinkley, R. L. (1990). Dimensions of conflict frame: Disputant interpretations of conflict. Journal of Applied Psychology, 75(2), 117-126. https:// doi.org/10.1037/0021-9010.75.2.117

49. Pondy, L. (1992). Reflections on organizational conflict. Journal of Organizational Behavior, 13(3), 257-261. https://doi.org/10.1002/ job.4030130305

50. Rahim, M. A. (1983). A Measure of Styles of Handling Interpersonal Conflict. Academy of Management Journal, 26(2), 368-376. https://doi. org/10.5465/255985

51. Rispens, S., Jehn,KA., \& Steinel, W. (2020). Conflict Management Style Asymmetry in ShortTerm Project Groups. Small Group Research, 1-23. https://doi. org/10.1177/1046496419894637

52. Smith, B. D. (2014). Capturing an elusive phenomenon: developing and testing a multiple perspective model of marketing strategy implementation. Journal of Strategic Marketing, 22(1), 16-40. https://doi. org/10.1080/0965254x.2013.817477

53. Tehrani, H. D., \& Yamini, S. (2020). Personality traits and conflict resolution styles: A meta-analysis. Personality and Individual Differences, 157, 109794. https://doi. org/10.1016/j.paid.2019.109794

54. Van den Assem, M. J., Van Dolder, D., \& Thaler, R. H. (2012). Split or steal? Cooperative behavior when the stakes are large. Management Science, 58(1), 2-20. https://doi. org/10.1287/mnsc.1110.1413

55. Vodosek, M. (2007). Intragroup conflict as a mediator between cultural diversity and work group outcomes. International Journal of Conflict Management, 18(4), 345-375. https://doi. org/10.1108/10444060710833469 